\title{
Peran Modal Sosial dalam Membangun Jejaring Pemasaran Formalin Nabati dari Tanaman Lamtoro Berbasis Kelompok Tani (Kasus di Kelompok Tani Werdi Gopala Desa Pucaksari, Kecamatan Busungbiu, Kabupaten Buleleng, Bali)
}

\author{
NI KETUT GAYATRI ADE PRATIWI AD, WAYAN SUDARTA, \\ NI WAYAN SRI ASTITI
}

\author{
Program Studi Agribisnis, Fakultas Pertanian, Universitas Udayana \\ Jalan PB Sudirman Denpasar 80323 \\ Email: gayatriadepratiwi@gmail.com \\ sudarta_wayan@ymail.com
}

\begin{abstract}
The role of social capital in the Werdi Gopala Farmer Group has not been maximally carried out in developing the network of plant formalin marketing, so it needs to be studied by using trust, social network, social norm, and cooperation. The purpose was to determine the role of social capital in building a marketing network of formalin of lamtoro plant and to find out the obstacles encountered in plant formalin market. This research was conducted in the Pucaksari Village, Busungbiu Sub-District, Buleleng Regency, Bali. The findings showed that the role of social capital in establishing farmer group-based marketing network of plant formalin in the case of Werdi Gopala Farmer Group of Pucaksari Village is classified in the medium category. The role of each indicator of social capital is the role of trust classified in good category. The role of social networks is categorized very poor. The role of social norms is classified as moderate category. The role of cooperation is classified as moderate category. The main obstacle faced by the farmer group in marketing plant formalin is technical aspect which covers condition of equipment that is not productive. The second constraint is from the economic aspect which includes the lack of capital to purchase the equipment used to produce plant formalin, and the absence of plant formalin marketing from the farmer group. Suggestions that can be given is that by improving social network by coaching farmer group to use printed media and social media to market formalin plant assisted by the agricultural extension or students in their community service in Pucaksari Village, increasing cooperation with company in agriculture, adding equipments to produce formalin plant and increasing the capital by submitting a proposal to the government to get equipments or capital aids.
\end{abstract}

Keywords: social capital, marketing, farmer groups and plant formalin

\section{Pendahuluan}

\subsection{Latar Belakang}

Dijelaskan oleh Pierre (dalam Ganarsih, 2011) modal sosial sebagai sumberdaya aktual dan potensial yang dimiliki oleh seseorang berasal dari jaringan yang 
terlembaga serta berlangsung terus menerus dalam bentuk pengakuan dan perkenalan timbal balik yang memberikan kepada anggotanya berbagai bentuk dukungan kolektif. Modal sosial pada dasarnya bersumber dari rasa percaya terhadap seseorang dalam melakukan interaksi. Dijelaskan oleh Soekanto (dalam Virgia, 2014) bahwa interaksi sosial merupakan kunci semua kehidupan sosial karena tanpa interaksi sosial, tak akan mungkin ada kehidupan bersama.

Pembangunan pertanian terus ditingkatkan melalui usaha-usaha intensifikasi, ekstensifikasi, dan diversifikasi. Tujuannya bukan saja untuk meningkatkan produksi pertanian dalam upaya memenuhi kebutuhan pangan dan meningkatkan ekspor, melainkan juga untuk meningkatkan arus transmigrasi dan untuk menjadikan sektor pertanian semakin kuat dalam usaha mendukung perkembangan industri (Sudarta, 2016).

Dijelaskan oleh Hanifan (dalam Syahra) modal sosial bukanlah modal dalam arti biasa seperti harta kekayaan atau uang, tetapi lebih mengandung arti kiasan, namun merupakan aset atau modal nyata yang penting dalam hidup bermasyarakat. Diungkapkan oleh Mawardi (dalam Holle, 2015) bahwa modal sosial yang berisikan kepercayaan, pertukaran timbal balik, norma-norma sosial, dan nilai-nilai etis, merupakan pondasi penompang yang akan menentukan perkembangan dan keberlanjutan beragam aktivitas usaha di berbagai sektor kehidupan.

Peran modal sosial sangat dibutuhkan dalam membangun pondasi dalam menompang usaha yang dimiliki oleh Kelompok Tani Werdi Gopala. Dinyatakan oleh Nuryanti dan Swastika (2011) kelompok tani dibentuk untuk memecahkan permasalahan yang dihadapi petani yang tidak bisa dipecahkan secara individu, kelompok tani dapat dibentuk secara swadaya maupun atas dasar kepentingan kebijakan dari pemerintah melalui Dinas Pertanian. Kelompok tersebut telah memproduksi beberapa produk seperti formalin nabati, pupuk organik, olahan dari susu kambing, biourine, biogas, dan bibit kopi. Pada kasus ini penulis memilih formalin nabati untuk produk yang akan diteliti. Kelompok tani ini memiliki permasalahan dalam bidang memasarkan formalin nabati. Formalin nabati memiliki manfaat untuk mengawetkan makanan, obat luka, bahkan sebagai obat gatal untuk kambing. Namun, kelompok tani ini belum melakukan promosi untuk produk formalin nabati. Dijelaskan oleh Muhamad Firdaus (2010) dalam bukunya yang berjudul "Manajemen Agribisnis" pemasaran merupakan salah satu dari kegiatan pokok yang harus dilakukan oleh para pengusaha termasuk pengusaha tani (agribusinessman) dalam usahanya untuk mempertahankan kelangsungan hidupnya, untuk mendapatkan laba, dan untuk berkembang. Maka dari itu, penulis mencoba untuk mengkaji lebih dalam peran modal sosial yang terdapat di Kelompok Tani Werdi Gopala dalam membangun jejaring pemasaran formalin nabati.

\subsection{Tujuan Penelitian}

Berdasarkan latar belakang yang sudah dijelaskan di atas, maka tujuan yang ingin dicapai dari penelitian ini, untuk mengetahui peran modal sosial dalam 
membangun jaringan pemasaran formalin nabati dari tanaman lamtoro berbasis kelompok tani. Selain itu, juga untuk mengetahui kendala yang dialami Kelompok Tani Werdi Gopala dalam memasarkan formalin nabati dari tanaman lamtoro.

\section{Metode Penelitian}

\subsection{Lokasi dan Waktu Penelitian}

Penelitian ini dilakukan di Desa Pucaksari, Kecamatan Busungbiu, Kabupaten Buleleng, Bali pada bulan Januari 2017. Penentuan lokasi penelitian menggunakan teknik purposive (sengaja).

\subsection{Data Penelitian}

\subsubsection{Jenis Data}

Jenis data yang digunakan meliputi data kualitatif dan kuantitatif. Data Kualitatif terdiri atas data-data yang berkaitan dengan peran modal sosial dalam membangun jejaring pemasaran formalin nabati dan kendala-kendala dalam pemasaran formalin nabati di Kelompok Tani Werdi Gopala Desa Pucaksari. Data kuantitatif yang didapat dari penelitian ini berupa gambaran umum dan karakteristik responden Kelompok Tani Werdi Gopala.

\subsubsection{Sumber Data}

Sumber data dari penelitian ini berupa data primer yang didapat meliputi karakteristik responden, data peran modal sosial dalam membangun jejaring pemasaran formalin nabati, serta kendala-kendala pada pemasaran formalin nabati. Data sekunder didapatkan berupa luas garapan responden dan struktur kepengurusan Kelompok Tani Werdi Gopala.

\subsubsection{Pengumpulan Data}

Pengumpulan data dilakukan dengan observasi, wawancara terstruktur, wawancara mendalam, dokumentasi, dan studi kepustakaan.

\subsubsection{Populasi, Responden, dan Informan Kunci}

Jumlah populasi dari penelitian ini yakni 15 orang atau seluruh anggota Kelompok Tani Werdi Gopala. Penentuan responden menggunakan metode sensus dan informan kunci sejumlah enam orang.

\subsection{Instrumen Penelitian}

Instrumen penelitian merupakan suatu tes yang bersifat mengukur karena berisikan tentang pertanyaan atau pernyataan yang jawabannya memiliki standar tertentu. Penelitian menggunakan dua instrument penelitian yakni kuisioner dan pedoman wawancara. Penyusunan kuisioner yang baik diperlukan uji validitas dan uji reliabilitas sebelum melaksanakan penelitian. Dijelaskan oleh Azwar (dalam Zulfikri, 2009) validitas berasal dari kata validity yang mempunyai arti sejauh mana ketepatan dan kecermatan suatu instrumen pengukur (tes) dalam melakukan fungsi ukurnya. Uji 
validitas ini dibantu dengan menggunakan aplikasi microsoft excel dengan $\mathrm{r}_{\text {tabel }}$ 1,734. Jadi kuisioner yang telah disebar dinyatakan valid dengan rhitung diatas rabel. Pengukuran koefisien reabilitas instrumen (Alpha Cronboach) menggunakan microsoft excel. Uji reabilitas ini diperoleh nilai alpha chronbach untuk kuisioner peran modal sosial dalam membangun jejaring pemasaran formalin nabati berbasis kelompok tani kasus di Kelompok Tani Werdi Gopala Desa Pucaksari yaitu 0,704.

\subsection{Variabel dan Pengukuran Variabel}

Berikut dapat dilihat konsep, variabel, indikator, dan skala pengukuran yang digunakan pada Tabel 1.

Tabel 1.

Konsep, Variabel, Indikator, dan Skala Pengukuran Peran Modal Sosial dalam Membangun Jaringan Pemasaran Berbasis Kelompok Tani, Tahun 2016

\begin{tabular}{|c|c|c|c|}
\hline Konsep & Variabel & Indikator & $\begin{array}{l}\text { Skala } \\
\text { Pengukuran }\end{array}$ \\
\hline \multirow{11}{*}{$\begin{array}{l}\text { Peran } \\
\text { Media } \\
\text { Sosial }\end{array}$} & \multirow[t]{6}{*}{ Kepercayaan } & $\begin{array}{l}\text { Kepercayaan terhadap ketua Kelompok } \\
\text { Tani }\end{array}$ & \multirow[t]{6}{*}{ Skala Likert } \\
\hline & & Werdi Gopala & \\
\hline & & $\begin{array}{l}\text { Kepercayaan terhadap sesama anggota } \\
\text { Kelompok Tani Werdi Gopala }\end{array}$ & \\
\hline & & $\begin{array}{l}\text { Kepercayaan pelanggan terhadap kualitas } \\
\text { formalin nabati yang diproduksi oleh } \\
\text { Kelompok Tani Werdi Gopala }\end{array}$ & \\
\hline & & $\begin{array}{l}\text { Kepercayaan pelanggan terhadap } \\
\text { kuantitas formalin nabati yang diproduksi } \\
\text { oleh Kelompok Tani Werdi Gopala }\end{array}$ & \\
\hline & & $\begin{array}{l}\text { Kepercayaan anggota kelompok terhadap } \\
\text { keberlanjutan dari produksi formalin } \\
\text { nabati }\end{array}$ & \\
\hline & \multirow[t]{2}{*}{$\begin{array}{l}\text { Jaringan } \\
\text { Sosial }\end{array}$} & $\begin{array}{l}\text { Penggunaan media sosial seperti WA, } \\
\text { BBM, Line untuk memasarkan formalin } \\
\text { nabati dari tanaman lamtoro }\end{array}$ & \multirow[t]{2}{*}{ Skala Likert } \\
\hline & & $\begin{array}{l}\text { Penggunaan Media cetak seperti koran, } \\
\text { majalah, brosur untuk mempromosikan } \\
\text { formalin nabati dari tanaman lamtoro }\end{array}$ & \\
\hline & \multirow[t]{3}{*}{$\begin{array}{l}\text { Norma } \\
\text { Sosial }\end{array}$} & $\begin{array}{l}\text { Peraturan tertulis yang terdapat pada } \\
\text { Kelompok Tani Werdi Gopala dalam } \\
\text { memproduksi formalin nabati dari } \\
\text { tanaman lamtoro }\end{array}$ & \multirow[t]{3}{*}{ Skala Likert } \\
\hline & & $\begin{array}{l}\text { Sanksi tertulis yang terdapat pada } \\
\text { Kelompok Tani Werdi Gopala dalam } \\
\text { memproduksi formalin nabati dari } \\
\text { tanaman lamtoro }\end{array}$ & \\
\hline & & $\begin{array}{l}\text { Peraturan tidak tertulis yang terdapat pada } \\
\text { Kelompok Tani Werdi Gopala dalam } \\
\text { memproduksi formalin nabati dari } \\
\text { tanaman lamtoro }\end{array}$ & \\
\hline
\end{tabular}




\begin{tabular}{|c|c|c|c|}
\hline & & $\begin{array}{l}\text { Sanksi tidak tertulis yang terdapat pada } \\
\text { Kelompok Tani Werdi Gopala dalam } \\
\text { memproduksi formalin nabati dari } \\
\text { tanaman lamtoro }\end{array}$ & \\
\hline & & $\begin{array}{l}\text { Adanya kerjasama yang dilakukan oleh } \\
\text { anggota Kelompok Tani Werdi Gopala } \\
\text { dalam memproduksi formalin nabati }\end{array}$ & \\
\hline & \multirow[t]{2}{*}{ Kerjasama } & $\begin{array}{l}\text { Adanya kerjasama dengan Dinas } \\
\text { Pertanian untuk memperkenalkan } \\
\text { formalin nabati dari tanaman lamtoro } \\
\text { yang diproduksi oleh Kelompok Tani } \\
\text { Werdi Gopala }\end{array}$ & Skala Likert \\
\hline & & $\begin{array}{l}\text { Adanya kerjasama dengan kelompok tani } \\
\text { lainnya yang terdapat di Kabupaten } \\
\text { Buleleng dalam memasarkan formalin } \\
\text { nabati dari tanaman lamtoro }\end{array}$ & \\
\hline \multirow[t]{4}{*}{$\begin{array}{l}\text { Kendala } \\
\text { Pemasaran } \\
\text { Formalin } \\
\text { Nabati }\end{array}$} & $\begin{array}{l}\text { Aspek } \\
\text { Teknis }\end{array}$ & $\begin{array}{l}\text { Peralatan yang digunakan untuk } \\
\text { memproduksi formalin nabati dari } \\
\text { tanaman lamtoro }\end{array}$ & Kualitatif \\
\hline & $\begin{array}{l}\text { Aspek } \\
\text { Sosial dan } \\
\text { Budaya }\end{array}$ & $\begin{array}{l}\text { Partisipasi dari anggota Kelompok Tani } \\
\text { Werdi Gopala tidak ada }\end{array}$ & Kualitatif \\
\hline & $\begin{array}{l}\text { Aspek } \\
\text { Budaya } \\
\text { Ekonomi }\end{array}$ & $\begin{array}{l}\text { Hasil atau keuntungan dari penjualan } \\
\text { formalin nabati dari tanaman lamtoro } \\
\text { tidak sesuai dengan keinginan anggota } \\
\text { Kelompok Tani Werdi Gopala }\end{array}$ & \multirow[t]{2}{*}{ Kualitatif } \\
\hline & Aspek & $\begin{array}{l}\text { Peralatan yang digunakan untuk } \\
\text { memproduksi formalin nabati dari } \\
\text { tanaman lamtoro }\end{array}$ & \\
\hline
\end{tabular}

\subsection{Batasan Operasional}

Modal sosial merupakan dasar yang menjadi landasan seseorang di dalam membangun hubungan sosial antara sesama anggota Kelompok Tani Werdi Gopala dalam membangun jejaringan pemasaran formalin nabati. Modal sosial dapat dikaji melalui kepercayaan, jaringan sosial, norma sosial, dan kerjasama. Kepercayaan merupakan kualitas individu dan organisasi yang mengacu pada nilai kejujuran, keterbukaan, rasa adil, dan kepedulian yang diberikan oleh Kelompok Tani Werdi Gopala. Jaringan sosial merupakan salah satu dimensi modal sosial yang lebih fokus pada aspek ikatan antar simpul yang bisa berupa hubungan antar orang atau kelompok untuk memasarkan formalin nabati. Norma sosial merupakan pedoman bagi perilaku dan tindakan seseorang yang bersumber dari nilai dalam membangun suatu jejaring pemasaran. Kerjasama yang berarti suatu usaha bersama antara perorangan atau kelompok untuk mencapai tujuan membangun jejaring pemasaran untuk formalin nabati. Kendala yang dirasakan oleh Kelompok Tani Werdhi Gopala dalam membangun jejaring pemasaran formalin nabati dapat dilihat dari aspek teknis, aspek sosial dan budaya, serta dari aspek ekonominya. 


\subsection{Metode Analisis Data}

Penelitian ini menggunakan analisis data deskriptif kualitatif, penulis mengulas atau menginterpretasikan data dan informasi yang disajikan dalam bentuk tabel-tabel atau data verbal yang dikumpulkan dari wawancara (interview) atau wawancara mendalam (depth interview), dan sama sekali tidak ada unsur pengujian statistik.

\section{Hasil dan Pembahasan}

\subsection{Gambaran Umum}

Kelompok Tani Werdi Gopala berdiri pada 14 Desember 2004 dan diketuai oleh Ketut Sirsa dengan jumlah anggota sebanyak 25 orang. Ketut Sirsa menjadi ketua selama dua periode dari tahun 2004 s.d 2009 dan 2009 s.d 2011. Pada tahun 2011 Ketut Sirsa digantikan oleh Made Widasna sebagai ketua kelompok dengan jumlah anggota 15 orang. Program-program yang dimiliki meliputi pembuatan bibit kopi, budidaya ternak kambing mulai dari pembibitan hingga penanganan pasca panennya, pembuatan pupuk organik, pemangkasan untuk kopi.

\subsection{Karakteristik Responden}

Penelitian ini menggunakan 15 orang sebagai responden yang merupakan pengurus dan anggota Kelompok Tani Werdi Gopala dan terlibat dalam produksi formalin nabati. Karakteristik responden akan dijelaskan berdasarkan jenis kelamin dan umur, tingkat pendidikan, penguasaan lahan, pekerjaan, dan jumlah anggota rumah tangga responden.

\subsubsection{Jenis Kelamin dan Umur}

Kelompok Tani Werdi Gopala terdiri dari 15 orang yang keseluruhannya berjenis kelamin laki-laki. Kelompok Tani Werdi Gopala terdiri dari orang-orang usia produktif dengan umur berkisaran 35-60 tahun. Rata-rata umur responden yakni 47 tahun.

\subsubsection{Tingkat Pendidikan}

Tingkat pendidikan anggota Kelompok Tani Werdi Gopala sebagian besar menempuh pendidikan menengah setingkat dengan SMP sampai SMA/SMK/STM sebanyak 53,6\%. 26,8\% telah menempuh pendidikan dasar yaitu SD dan 19,6\% menempuh pendidikan tinggi atau setara dengan diploma dan sarjana. Rata-rata tingkat pendidikan responden tamatan sekolah menengah yakni SMP atau SMA/SMK.

\subsubsection{Penguasaan Lahan}

Berdasarkan data yang didapat dari lapangan luas garapan responden dihitung berdasarkan total garapan milik sendiri dan milik orang lain. Rata-rata luas garapan perkebunan/tegalan milik sendiri seluas 1,33 ha dan milik orang lain rata-rata 2,15 ha dengan komoditi yang ditanam berupa kopi. Luas garapan pekarangan milik sendiri seluas 0,042 ha dan milik orang lain rata-rata 0,055 ha. 


\subsubsection{Pekerjaan}

Sebagian besar anggota Kelompok Tani Werdi Gopala pekerjaan utama Kelompok Tani Werdi Gopala sebagai petani. Namun terdapat dua orang yang pekerjaan utamanya menjadi guru dan pegawai swasta, dimana pekerjaan sampingannya sebagai petani.

\subsubsection{Jumlah Anggota Rumah Tangga Responden}

Data yang terdapat di lapangan jumlah anggota rumah tangga $<3$ orang sebanyak $80,2 \%$ tergolong jumlah anggota rumah tangga yang sedikit dan tanggungan di keluarga juga tidak besar. Jumlah anggota rumah tangga 3-5 orang sebanyak 13,2\% yang berarti jumlah anggota keluarga dan tanggungan masih standar tidak begitu banyak dan tidak begitu sedikit. Jumlah anggota rumah tangga $>5$ orang sebanyak $6,6 \%$ sehingga tanggungan dalam keluarga sangat banyak karena jumlah anggota keluarga yang banyak. Rata-rata jumlah anggota rumah tangga responden sebanyak 3 orang.

\subsection{Peran Modal Sosial}

Peran modal sosial pada Kelompok Tani Werdi Gopala belum maksimal dalam membangun jejaring pemasaran formalin nabati dari tanaman lamtoro, sehingga perlu dikaji dengan menggunakan kepercayaan, jaringan sosial, norma sosial, dan kerjasama. Hasil dari pengkajian ini menyatakan bahwa peran modal sosial dalam membangun jejaring pemasaran formalin nabati dari tanaman lamtoro berbasis kelompok tani tergolong sedang dengan skor 3,0.

Peran kepercayaan tergolong baik dengan skor 3,9. Peran kepercayaan merupakan salah satu indikator yang memiliki skor tertinggi dibandingkan indikator lainnya. Peran kepercayaan yang dikaji pada penelitian ini yakni kepercayaan terhadap ketua kelompok, sesama anggota kelompok, kualitas dari formalin nabati, kuantitas dari formalin nabati, dan keberlanjutan dari formalin nabati.

Peran jaringan sosial tergolong sangat tidak baik dengan pencapaian skor 1,3. Peran jaringan sosial merupakan salah satu indikator yang memiliki skor terendah. Hal ini disebabkan dari media-media yang digunakan Kelompok Tani Werdi Gopala dalam memasarkan formalin nabati tidak dijalankan, seperti halnya media cetak dan media sosial yang mampu membantu kelompok tani ini memperkenalkan formalin nabati justru tidak dijalankan oleh kelompok ini. Jaringan sosial yang sangat tidak baik juga disebabkan tingkat pendidikan dari responden, sebagian besar responden tamatan SMP atau SMA/SMK. Sehingga media sosial dan media cetak sulit untuk diterapkan. Peran norma sosial tergolong sedang dengan pencapaian skor 3,0.

Peran norma sosial terdiri dari peraturan tertulis, sanksi tertulis, peraturan tidak tertulis dan sanksi tidak tertulis. Norma sosial yang terdapat di dalam Kelompok Tani Werdi Gopala belumlah berjalan dengan maksimal dikarenakan sanksi yang terdapat di dalamnya belumlah jelas sehingga norma tidak dapat berjalan dengan baik. 
Peran kerjasama tergolong sedang dengan skor 3,3. Peran kerjasama yang terdapat pada penelitian ini yakni intern dan ekstern. Kerjasama di intern dilihat dari kekompokan dari anggota Kelompok Tani Werdi Gopala dalam memproduksi formalin nabati. sedangkan diekstern kerjasama dilihat dari kerjasama yang dilakukan dengan pihak pemerintah dan perusahaan-perusahaan. Namun, kerjasama yang dilakukan ke perusahaan tidak berjalan baik karena belum memiliki mitra kerja. Berikut dapat dilihat peran modal sosial dalam membangun jejaring pemasaran formalin nabati dari tanaman lamtoro pada Tabel 2.

\section{Tabel 2.}

Peran Modal Sosial dalam Membangun Jejaring Pemasaran Formalin Nabati dari Tanaman Lamtoro Berbasis Kelompok Tani Kasus di Kelompok Tani Werdi Gopala Desa Pucaksari, Tahun 2017

\begin{tabular}{|c|c|c|c|}
\hline No & Indikator Peran Modal Sosial & Skor & Kategori \\
\hline \multirow[t]{6}{*}{1} & Kepercayaan & 3,9 & Baik \\
\hline & Kepercayaan terhadap ketua kelompok & 4,4 & Sangat Baik \\
\hline & Kepercayaan terhadap sesama Anggota & 4,5 & Sangat Baik \\
\hline & Kepercayaan terhadap kualitas formalin nabati & 3,3 & Baik \\
\hline & Kepercayaam terhadap Kuantitas formalin nabati & 3,5 & Baik \\
\hline & Kepercayaan terhadap keberlanjutan formalin nabati & 3,7 & Baik \\
\hline \multirow[t]{3}{*}{2} & Jaringan Sosial & 1,3 & $\begin{array}{l}\text { Sangat Tidak } \\
\text { Baik }\end{array}$ \\
\hline & Media sosial yang digunakan dalam memasarkan formalin nabati & 1,3 & $\begin{array}{l}\text { Sangat Tidak } \\
\text { Baik }\end{array}$ \\
\hline & Media cetak yang digunakan dalam memasarkan formalin nabati & 1,3 & $\begin{array}{l}\text { Sangat Tidak } \\
\text { Baik }\end{array}$ \\
\hline \multirow[t]{5}{*}{3} & Norma Sosial & 3,0 & Sedang \\
\hline & Peraturan tertulis & 4,1 & Baik \\
\hline & Sanksi tertulis & 1,7 & $\begin{array}{l}\text { Sangat Tidak } \\
\text { Baik }\end{array}$ \\
\hline & Peraturan tidak tertulis & 3,7 & Baik \\
\hline & Sanksi tidak tertulis & 2,7 & Tidak Baik \\
\hline \multirow[t]{5}{*}{4} & Kerjasama & 3,3 & Sedang \\
\hline & $\begin{array}{l}\text { Kekompakan anggota kelompok dalam memasarkan formalin } \\
\text { nabati }\end{array}$ & 4,3 & Sangat baik \\
\hline & Kerjasama tehadap instansi pemerintah seperti dinas & 3,9 & Baik \\
\hline & Kerjasama dengan perusahaan dalam memasrkan formalin nabati & 1,6 & $\begin{array}{l}\text { Sangat Tidak } \\
\text { Baik }\end{array}$ \\
\hline & Peran Media Sosial & 3,0 & Sedang \\
\hline
\end{tabular}

\subsection{Kendala-kendala pada Pemasaran Formalin Nabati}

Kegiatan pemasaran formalin nabati tidak terlepas dari kendala-kendala yang dihadapi selama menjalankan kegiatan tersebut. Kendala-kendala tersebut dikaji dari aspek teknis, sosial dan budaya, ekonomi. Kendala utama yang dirasakan dalam pemasaran formalin nabati berasal dari aspek teknis. Aspek ini meliputi peralatan yang digunakan untuk memproduksi formalin nabati. Saat ini kondisi dari peralatan 
yang digunakan untuk memproduksi formalin nabati mulai menunjukkan gejala tidak produktif sehingga menghambat produksi formalin nabati. Selain itu, jumlah alat yang berupa tungku besar berjumlah satu buah sehingga hal ini menghambat Kelompok Tani Werdi Gopala dalam memproduksi formalin nabati dalam kapasitas banyak.

Kendala kedua yang dihadapi Kelompok Tani Werdi Gopala yaitu dari aspek ekonomi. Kelompok Tani Werdi Gopala selama ini belum melakukan pemasaran langsung mengenai formalin nabati. Selama ini, kelompok tersebut hanya menjual formalin nabati kepada sesama anggota kelompok saja, untuk penjualan keluar kelompok ini belum memasarkannya. Kendala pada aspek ekonomi yaitu belum adanya pemasaran dan kekurangan modal untuk membeli alat (tungku besar) yang digunakan untuk memproduksi formalin nabati. Kendala ketiga yaitu aspek sosial dan budaya yang meliputi kesibukan dari masing-masing anggota dan hal ini tidak terlalu berpengaruh dengan produksi formalin nabati.

\section{Simpulan dan Saran}

\subsection{Simpulan}

Peran modal sosial dalam membangun jejaring pemasaran formalin nabati dari tanaman lamtoro berbasis kelompok tani di Kelompok Tani Werdi Gopala tergolong sedang. Hal ini dikaji dari kepercayaan dengan indikator baik, jaringan sosial dengan indikator sangat tidak baik, norma sosial, dan kerjasama dengan indikator sedang.

Kendala yang dihadapi dari aspek teknis yaitu keterbatasan peralatan yang digunakan untu memproduksi formalin nabati, sehingga tidak dapat memenuhi permintaan pasar yang cukup banyak. Kendala yang dihadapi dari aspek sosial dan budaya yakni kesibukan dari masing-masing anggota yang berbeda-beda. Kendala pada aspek ekonomi yaitu dari keterbatasan modal, sulit memasarkan, tidak menguntungkan.

\subsection{Saran}

Berdasarkan simpulan tersebut maka disarankan Kelompok Tani Werdi Gopala sebagai berikut.

1. Memberikan fasilitas kepada kelompok ini untuk belajar menggunakan media sosial maupun media cetak untuk memasarkan formalin nabati dan dapat dibantu oleh PPL maupun mahasiswa KKN di Desa Pucaksari.

2. Menambah kerjasama dengan perusahaan-perusahaan yang bergelut dibidang pertanian, perkebunan, atau peternakan supaya penjualan formalin nabati lebih meningkat lagi.

3. Membeli alat baru dengan menggunakan sebagian uang kas dan iuran dari anggota kelompok, dan memohon bantuan kepada Dinas Pertanian Kabupaten Buleleng untuk memdapatkan peralatan yang baru dengan cara mengajukan proposal ke Dinas Pertanian Kabupaten Buleleng. 
4. Menaikan iuran supaya kas yang dimiliki Kelompok Tani Werdi Gopala bertambah banyak dan dapat membeli tungku untuk memproduksi formalin nabati.

5. Melakukan promosi untuk formalin nabati yang dimulai dari sosialisasi di Desa Pucaksari mengenai formalin nabati, sehingga dengan cara tersebut informasi mengenai formalin nabati dapat disebarluaskan dari mulut ke mulut.

\section{$5 \quad$ Ucapan Terimakasih}

Penulis mengucapkan terimakasih kepada semua pihak yang telah membantu penelitian dan sampai termuat di e jurnal.

\section{Daftar Pustaka}

Amin, Syamsiar. 2016. Pengaruh Unsur Modal Sosial Terhadap Keberhasilan Kelompok Tani Ternak Penerima Bantuan Program Sarjana Membangun Desa (Smd) Di Kabupaten Bone. [Online]. Tersedia : http://repository.unhas.ac.id. Html [25 Juli 2016]

Fatnar, Virgia Ningrum dan Choirul Anam. 2014. Kemampuan Interaksi Sosial Antara Remaja Yang Tinggal Di Pondok Pesantren Dengan Yang Tinggal Bersama Keluarga. Dalam EMPATHY, Jurnal Fakultas Psikologi Vol. 2, No 2, Desember 2014 ISSN : 2303-114X (online). Html [14 Februari 2017]

Firdaus, Muhamad. 2010. Manajemen Agribisnis. Bumi Aksara : Jakarta

Garnasih, Rahmi. 2011. Peran Modal Sosial dalam Pemberdayaan Perempuan Pada Sektor Informal (Studi Kasus Pada Pedagang Warung Nasi Di Pasar Depok Lama Pancoran Mas Depok. [Online]. Tersedia: http://repository.uinjkt.ac.id. Html [24 Juli 2016]

Holle, Yolanda. 2015. Modal Sosial Suku Marind dalam Pengembangan Padi Sawah di Kabupaten Merauke Provinsi Papua. Universitas Udayana : Denpasar.

Matondang, Zulklifi. 2009. Validitas dan Reliabilitas Suatu Instrumen Penelitian. Jurnal Tabularasa Pps Unimed Vol.6 No.1, Juni 2009 (Online)

Nuryanti, Sri \& Dewa K.S Swastika. (2011) . Peran Kelompok Tani dalam Penerapan Teknologi Pertanian.[Online]. Tersedia : http://pse.litbang.pertanian.go.id. Html [2 April 2016]

Ruslan, Rosady. 2004. Metode Penelitian Public Relation dan Komunikasi. 2004. PT Raja Grafindo Persada, Jakarta

Sudarta, Wayan. 2016. Sosiologi Pertanian. Udayana University Press : Denpasar.

Syahra, Rusydi. Modal Sosial: Konsep dan Aplikasi. [Online]. Tersedia : jmblipi.or.id/index.php/jmb/article/download/256/234. Html [23 Juli 2016] 